RASĀYAN J. Chem.

Vol. 13 | No. 1 |1 - 10| January - March | 2020 ISSN: 0974-1496 | e-ISSN: 0976-0083 | CODEN: RJCABP http://www.rasayanjournal.com http://www.rasayanjournal.co.in

\title{
THE EFFECTIVENESS OF AQUAPONIC COMPARED TO MODIFIED CONVENTIONAL AQUACULTURE FOR IMPROVED OF AMMONIA, NITRITE, AND NITRATE
}

\author{
Deswati $^{1, *}$, Amelliza Deviona $^{1}$, Ella Intan Sari ${ }^{1}$, Yulizar Yusuf ${ }^{1}$ \\ and Hilfi Pardi ${ }^{2}$ \\ ${ }^{1}$ Department of Chemistry, Faculty of Mathematics and Natural Science, \\ Andalas University, Kampus Limau Manis, Padang 25163, Indonesia \\ ${ }^{2}$ Department of Chemistry Education, Faculty of Teacher Training and Education Raja Ali Haji \\ Maritime University, Senggarang, Tanjungpinang, Indonesia \\ *E-mail: deswati@sci.unand.ac.id
}

\begin{abstract}
Indonesia is currently faced with a variety of problems, including relating to increasing food demand and prices, increasingly scarce clean water, and poverty. Therefore, the development of aquaponics technology has been carried out, which integrates aquaculture and hydroponics. This study was conducted to compare water quality ( $\mathrm{pH}$, temperature, ammonia, nitrite, and nitrate) produced from 2 different systems, namely aquaponic with modified conventional aquaculture systems. In an aquaponic system, water recirculation follows the steps: Water from a fish pond tank (FPT), flows to mechanical tanks-1(MT-1), biofilter tanks (BT), mechanical tanks-2 (MT-2), to hydroponic plants (HP), and finally back to FPT, and so on. While conventional aquaculture systems, water recirculation is only through $\mathrm{FPT}, \mathrm{MT}$, and $\mathrm{BT}$. The results were obtained for aquaponic (ammonia 0.350-5.946 $\mathrm{mg} / \mathrm{L}$, nitrite $0.193-0.880 \mathrm{mg} / \mathrm{L}$ and nitrate $1.031-5.542 \mathrm{mg} / \mathrm{L}$ ), and for modified conventional aquaculture systems (ammonia $0.350-9.353 \mathrm{mg} / \mathrm{L}$, nitrite $0.114-0.880 \mathrm{mg} / \mathrm{L}$ and nitrate $0.949-1.031 \mathrm{mg} / \mathrm{L}$ ). While the $\mathrm{pH}$ and temperature values for the two systems are the same, $\mathrm{pH} 7.18-8.9$, and water temperature $26.7-30.0^{\circ} \mathrm{C}$. After the ttest, both showed a significant difference where the aquaponics system was better than the modified conventional aquaculture system because the aquaponic system was supported by the presence of MT-1, BT, MT-2, HP, and FPT, while the modified conventional aquaculture systems were only supported by MT, BT, and FPT.
\end{abstract}

Keywords: Aquaponic, Modified Conventional Aquaculture, Ammonia, Nitrite, Nitrate

(C) RASĀYAN. All rights reserved

\section{INTRODUCTION}

Indonesia is one of the developing countries, some of the problems encountered are increasing food demand, rising food prices, scarcity of clean water, and poverty. Another obstacle is the reduction in agricultural land, along with the increase in the number of population increases, so that the increasing number of people such as the measuring series is not comparable to food needs. One of the technologies that are feasible to develop is aquaponics technology supported by biofilter so that optimal water quality is obtained..$^{1-2}$

Based on the results of the research that has been done, show that the application of biofiltration ponds can increase production, land use and can save water usage during fish maintenance, while aquaponics systems are an integration between hydroponic plants and aquatic aquaculture, and become one of the effective solutions for food supply during the land crisis began to occur. ${ }^{3}$ In aquaponic systems, waste products from a biofilter system will be used as a nutrient. Waste from aquaculture animals will be used as a nutrient for hydroponic plants. The use of wastewater from aquaponic animals will be filtered, so as to produce water that can be a nutrient for hydroponic plants. The process is carried out repeatedly which is known as the recirculation system. The aquaponics system has many advantages, namely saving land

Rasayan J. Chem., 13(1), 1-10(2020)

http://dx.doi.org/10.31788/RJC.2020.1315427

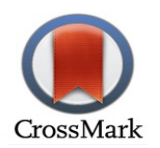


RASĀYAN J. Chem.

Vol. 13 | No. 1 |1 - 10| January - March | 2020

use and water, being environmentally friendly, producing organic fertilizers for plants, producing food products that have good quality and high nutritional value and can improve the economy. ${ }^{4}$

Aquatic animal wastewater, sourced from fish feces and the rest of fish food that accumulates and contains a lot of ammonia $\left(\mathrm{NH}_{3}\right)$, so it is toxic to cultivated organisms and can inhibit fish growth. ${ }^{5}$ In aquaponic systems, ammonia from the waste products from aquatic animals will be converted by decomposing bacteria that live on culture walls, planting media and filter media. Nitrosomonas sp bacteria will convert ammonia $\left(\mathrm{NH}_{3}\right)$ to nitrite $\left(\mathrm{NO}_{2}{ }^{-}\right)$then nitrite $\left(\mathrm{NO}_{2}{ }^{-}\right)$is converted to nitrate $\left(\mathrm{NO}_{3}{ }^{-}\right)$ with the bacteria Nitrobacter sp, and then the nitrate conversion results are organic fertilizers so that the results of the research that have been done showed that the application of biofiltration ponds was able to increase production, land use and be able to save water usage during fish maintenance, while aquaponics systems are an integration between hydroponic plants and aquatic aquaculture, and become one of the effective solutions for food supply when land crises begin. ${ }^{3}$ In aquaponic systems, waste products from a biofilter system will be used as a nutrient. Waste from aquaculture animals will be used as a nutrient for hydroponic plants. The use of wastewater from aquaponic animals will be filtered, so as to produce water that can be a nutrient for hydroponic plants. The process is carried out repeatedly which is known as the recirculation system. The aquaponics system has many advantages, namely saving land use and water, being environmentally friendly, producing organic fertilizers for plants, producing food products that have good quality and high nutritional value and can improve the economy. ${ }^{4}$

Aquatic animal wastewater, sourced from fish feces and the rest of fish food that accumulates and contains a lot of ammonia $\left(\mathrm{NH}_{3}\right)$, so it is toxic to cultivated organisms and can inhibit fish growth ${ }^{5}$. In aquaponic systems, ammonia as the waste products from aquatic animals will be converted by decomposing bacteria that live on culture walls, planting media and filter media. Nitrosomonas sp bacteria will convert ammonia $\left(\mathrm{NH}_{3}\right)$ to nitrite $\left(\mathrm{NO}_{2}{ }^{-}\right)$then nitrite $\left(\mathrm{NO}_{2}{ }^{-}\right)$is converted to nitrate $\left(\mathrm{NO}_{3}{ }^{-}\right)$ with the bacteria Nitrobacter sp, and then the nitrate conversion is an organic fertilizer so that it can help the process of hydroponic plant growth. ${ }^{6-7}$

Aquaponics technology is proven to be able to produce fish optimally on narrow land and limited water sources so that with the combination of these technologies it is expected that households can meet food for consumption and can increase their income. Furthermore, the use of aquaponic technology can save land and water use, it can also improve business efficiency through the utilization of nutrients from the rest of the feed and metabolism of fish and is one of the environmentally-friendly fish farming systems. ${ }^{8}$ The hydroponic plants used in the aquaponic system in this study are Pakcoy (Brassica rapa L), which is one of the leafy vegetables that have high nutritional value, relatively fast planting time, can grow in the highlands and lowlands and has high economic value ${ }^{9}$, using Rockwool planting media and nutrients for plants derived from nitrates from ammonia reshuffle on aquaponic systems. ${ }^{7-8}$

Aquatic animals are chosen by Orechromis niloticus, because these aquatic fish have relatively fast growth, can tolerate poor water quality, have a high tolerance to high salinity, high water temperature, low dissolved oxygen, and high concentrations of ammonia, and Orechromis niloticus is suitable for cultivation in the area tropical. ${ }^{7-8,10}$ This study was conducted to compare water quality in an aquaponic system with a modified conventional aquaculture system.

\section{Tools and Materials}

EXPERIMENTAL

The tools used in this study were UV-Vis spectrophotometers (Shimadzu, UV-2700), analytical balance sheets, fish ponds, water pumps, water tanks, PVC pipes, net pots, aerators, and glassware commonly used in laboratories.

The materials used in this study were tilapia, fish feed, Pakcoy plants, planting media (Rockwool), water as much as $3 \mathrm{~m}^{3}$, and chemicals for analysis of water quality.

\section{Series of Aquaponic And Modified Conventional Aquaculture Systems}

The aquaponic and modified conventional aquaculture systems (Fig.-1) use a series of water streams consisting of FPT (diameter $300 \mathrm{~cm}$ and height $100 \mathrm{~cm}$ ), MT $\left(150 \mathrm{dm}^{3}\right)$, and BT $\left(150 \mathrm{dm}^{3}\right)$. Especially for 
RASĀYAN J. Chem.

Vol. 13 | No. 1 |1 - 10| January - March | 2020

modified conventional aquaculture systems are not equipped with hydroponic plants, and there is only 1 MT.
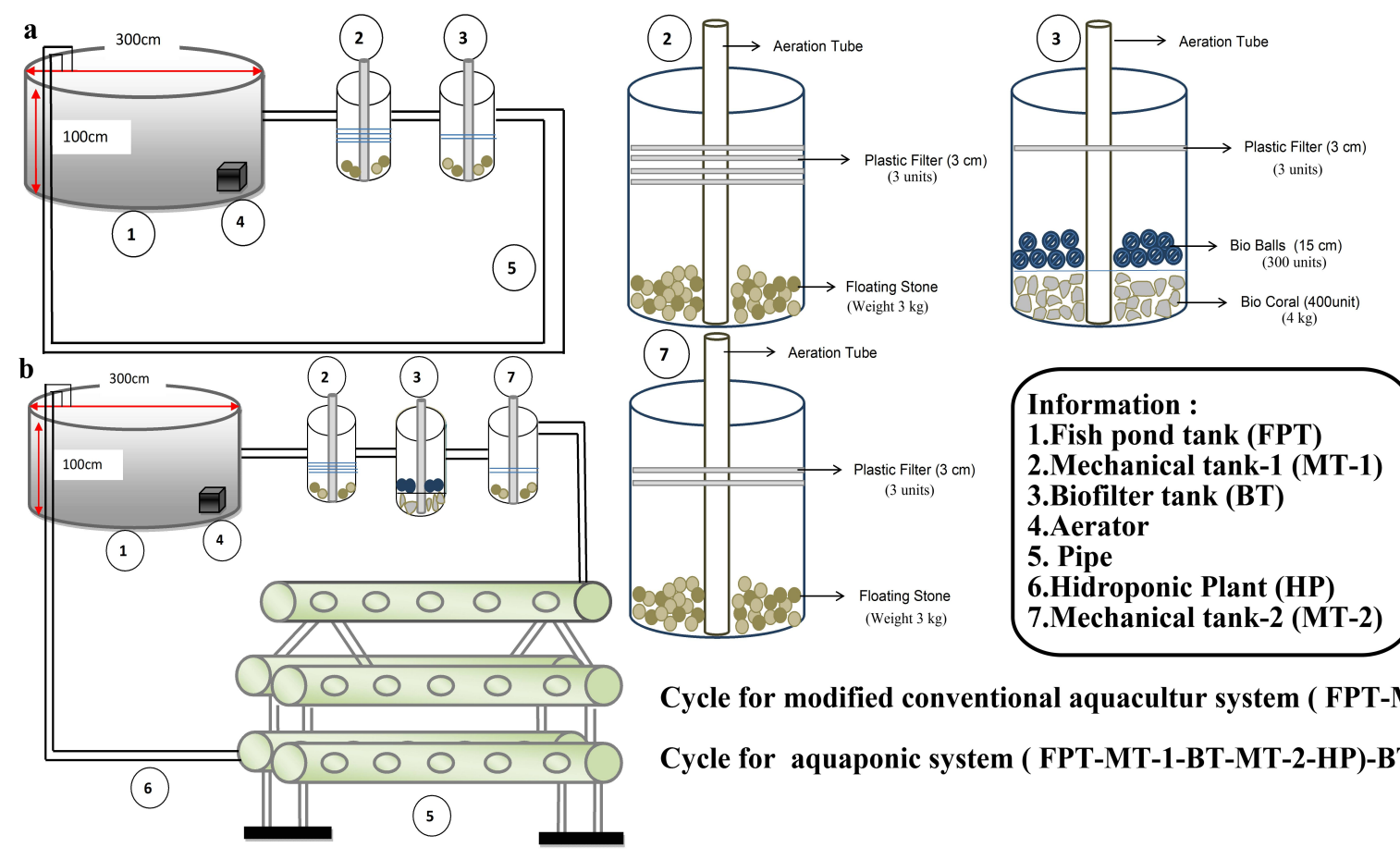

Cycle for modified conventional aquacultur system ( FPT-MT-BT)

Cycle for aquaponic system ( FPT-MT-1-BT-MT-2-HP)-BT)

Research Procedure

Fig.-1: Modified Conventional Aquaculture Systems (a); Aquaponic Systems (b)

FPT is filled with fresh water as much as $3 \mathrm{~m}^{3}$, furthermore, water is given oxygen so that oxygen needs can be met, and during sampling, aeration is turned off. The stocked fish is Oreochromis niloticus, the size of length $\pm 3-5 \mathrm{~cm}$, weight $\pm 4 \mathrm{~g} /$ piece using a stocking density of $500 \mathrm{fish} / 3 \mathrm{~m}^{3}$ of water.

Before the fish are stocked into fish ponds, acclimatization is carried out with the aim that the fish are not stressed, and die. The fish feed (pellet) used was Prima Feed PF 1000 mixed with Nitrosomonas bacteria and given to fish at a dose of $2 \mathrm{~kg}$ of fish feed per $50 \mathrm{~mL}$ opak pdferia.

The composition of MT consists of plastic filters (thick $3 \mathrm{~cm}, 3$ units), and floating stone (as much as 3 $\mathrm{kg}$ ), used to filter fish food that is not eaten, fish feces and other impurities, before entering BT. Furthermore, BT composition is a plastic filter ( $3 \mathrm{~cm}$ thick, 3 units), bio ball (300 units), biocoral (4 kg), which functions as a bacterial growth medium. Then flow to MT-2, to HP, and return to FPT again, and water recirculation begins again and continuously.

\section{Preparation of Planting Media}

The planting media used is Rockwool with a size of $40 \times 30 \mathrm{~cm}$, then cut into $1 \times 1 \mathrm{~cm}$ to facilitate the transfer of seedlings from the seedling media into the netpot. Netpot functions as a medium to support plants so that plant stems can stand firmly, netpots are associated with the flannel cloth which functions as an absorbent of water that passes through the system, so that the water can be stored in the planting media, and nutrients in the water can be absorbed by plants. Pakcoy plant seeds are sown for 2 weeks before being transferred to the hydroponic circuit. The number of Pakcoy plant seeds in the hydroponic sequence is 40 seeds.

\section{Data Analysis}

This study was conducted for 40 days, namely days $0,10,20$, and 40 . Water quality parameters measured in aquaponic systems and modified conventional aquaculture systems: temperature $\left({ }^{\circ} \mathrm{C}\right), \mathrm{pH}$, ammonia 
RASĀYAN J. Chem.

Vol. 13 | No. 1 |1 - 10| January - March | 2020

$(\mathrm{mg} / \mathrm{L})$, nitrite $(\mathrm{mg} / \mathrm{L})$, and nitrate $(\mathrm{mg} / \mathrm{L})$. The limit of optimal tolerance allowed for plant, fish and bacteria is probably not the same (Table-1), compromising water quality is needed (Tabel-2). ${ }^{11}$ Furthermore, water quality data from both systems are compared using the t-test.

Table-1: Water Quality Tolerance For Fish, Hydroponic Plants and Nitrifying Bacteria

\begin{tabular}{c|c|c|c|c|c}
\hline Organism type & $\operatorname{Temp}\left({ }^{0} \mathrm{C}\right)$ & $\mathrm{pH}$ & Ammonia $(\mathrm{mg} / \mathrm{L})$ & Nitrite $(\mathrm{mg} / \mathrm{L})$ & Nitrate $(\mathrm{mg} / \mathrm{L}$ \\
\hline Fish & $22-32$ & $6-8.5$ & $<3$ & $<1$ & $<400$ \\
\hline Plants & $16-30$ & $5.5-7.5$ & $<30$ & $<1$ & - \\
\hline Bacteria & $14-34$ & $6-8.5$ & $<3$ & $<1$ & - \\
\hline
\end{tabular}

Table-2: The Ideal Parameter For Aquaponics As A Compromise Between the Three Organisms

\begin{tabular}{c|c|c|c|c|c}
\hline Plants & $\operatorname{Temp}\left({ }^{0} \mathrm{C}\right)$ & $\mathrm{pH}$ & Ammonia $(\mathrm{mg} / \mathrm{L})$ & Nitrite $(\mathrm{mg} / \mathrm{L})$ & Nitrate $(\mathrm{mg} / \mathrm{L}$ \\
\hline Bacteria & $18-30$ & $6-7$ & $<1$ & $<1$ & $5-150$ \\
\hline
\end{tabular}

In aquaponic systems, water samples are taken from FPT, MT-1, BT, HP, and MT-2, whereas in the modified conventional aquaculture system, water samples were taken from FPT, MT, and BT.

\section{Analysis of Ammonia}

\section{RESULTS AND DISCUSSION}

Ammonia can affect water quality if the amount has exceeded the permissible threshold. The source of ammonia in aquaculture is waste food that is not eaten, feces, and dead organisms, and are toxic. Therefore, the toxic waste must be converted so it is not dangerous for the survival and growth of fish. ${ }^{7,12}$ The results of the studies that have been conducted, the ammonia content in the aquaponics and modified conventional aquaculture systems can be seen in Fig.-2.

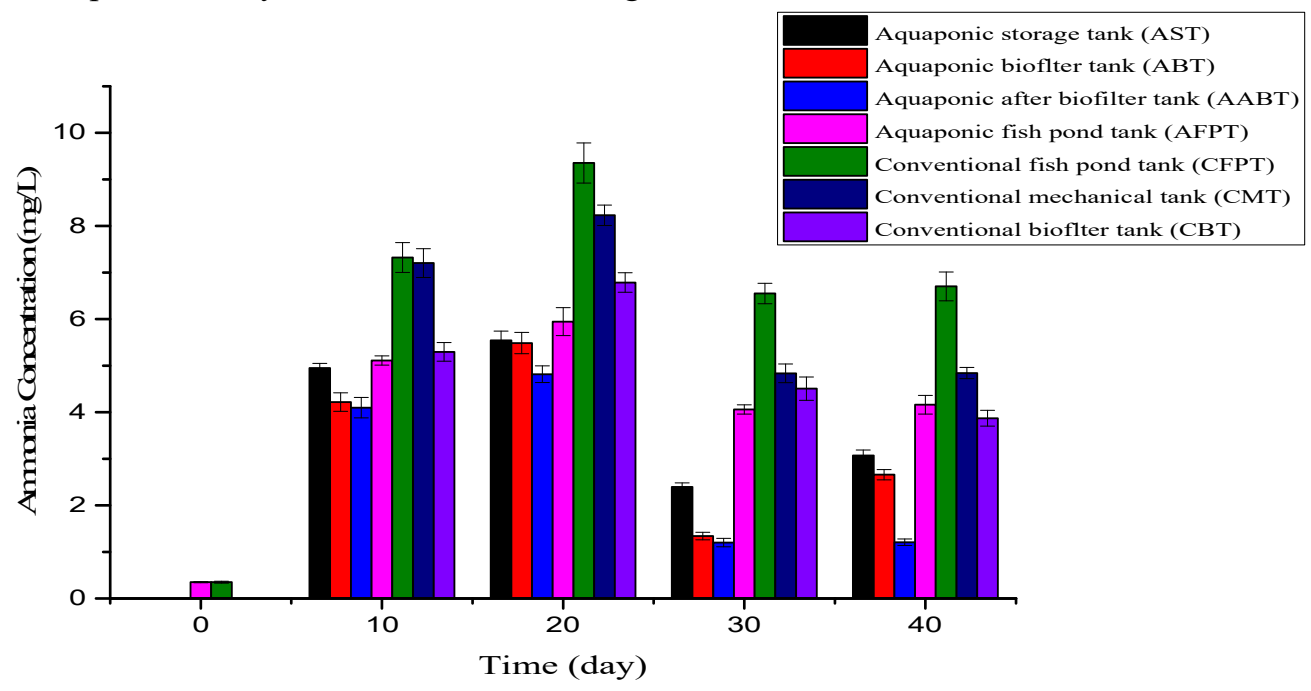

Fig.-2: Ammonia Concentration (mg/L) in Aquaponic and Modified Conventional Aquaculture

Based on Fig.-2, the ammonia content in the 0 the day is $0.350 \mathrm{mg} / \mathrm{L}$. The sample on day 0 is a water source that will be used in a series of aquaponic and modified conventional aquaculture systems. On day 0 , low ammonia levels were obtained, because the process of the aquaponics and the conventional aquaculture system had not yet begun.

In the aquaponic system, the concentration of ammonia on the $10^{\text {th }}$ day in the FPT was $5.111 \mathrm{mg} / \mathrm{L}, \mathrm{MT}$ 1 was $4.950 \mathrm{mg} / \mathrm{L}$, BT was $4.218 \mathrm{mg} / \mathrm{L}$, MT-2 was $4.098 \mathrm{mg} / \mathrm{L}$, and the HP was $3.763 \mathrm{mg} / \mathrm{L}$. Compared with ammonia levels on day 0 with the $10^{\text {th }}$ day there was an increase because on the $10^{\text {th }}$ day, the aquaponics system was already operating even though it was not optimal. Ammonia levels in FPT are higher because of the results of fish metabolism and fish food leftovers in fish ponds, which are the main 
RASĀYAN J. Chem.

Vol. 13 | No. 1 |1 - 10| January - March | 2020

sources of ammonia. ${ }^{12}$ In the MT-1, there is a slight decrease in ammonia levels because there is a filter in the MT-1, so there is a quite different decrease in the BT due to the presence of nitrifying bacteria. On the $20^{\text {th }}$ day, there was an increase in ammonia levels in each tank. This is because nitrifying bacteria contained in the tank have not worked optimally and the rate of growth of fish, resulting in more metabolism than the previous day.

On the $30^{\text {th }}$ day, the concentration of ammonia in the tank decreased. In FPT, ammonia levels were 4.060 $\mathrm{mg} / \mathrm{L}$, MT-1 $2.394 \mathrm{mg} / \mathrm{L}$, BT $1.341 \mathrm{mg} / \mathrm{L}$, MT-2 $1.202 \mathrm{mg} / \mathrm{L}$, and HP was $0.176 \mathrm{mg} / \mathrm{L}$. In general, the concentration of ammonia on the $30^{\text {th }}$ day decreased from the $20^{\text {th }}$ day. This is because the nitrification process has worked optimally. In the BT, MT-2 and HP, there was a significant decrease from the previous day, due to the presence of bacteria that had been converted into nitrate in the tank, so that the ammonia content was smaller.

Ammonia concentration on the $40^{\text {th }}$ day was not significantly increased in FPT was $4.161 \mathrm{mg} / \mathrm{L}$, MT-1 was 3.069 , BT was $2.659 \mathrm{mg} / \mathrm{L}$, MT-2 was $1.208 \mathrm{mg} / \mathrm{L}$, and HP was $1.183 \mathrm{mg} / \mathrm{L}$. Ammonia levels on day 40 increased compared to 30 days, which is directly proportional to the increase in $\mathrm{pH}$ and temperature. If the $\mathrm{pH}$ value and temperature increase, the ammonia content will also increase. ${ }^{13}$ The high ammonia level in water is accompanied by a reduction in water dissolved oxygen (DO). This is because nitrifying bacteria are aerobic bacteria that require oxygen in the nitrification process. If the oxygen content in the water is a little it will disrupt the course of the nitrification process. As a result, nitrifying bacteria cannot work optimally in converting ammonia to nitrate, so that the content of ammonia in the water increases. In accordance with the research conducted ${ }^{14}$, if the dissolved oxygen content in water is low, the ammonia level in the water will increase.

Based on Figure 2, there is a significant difference between the concentration of ammonia in a modified conventional aquaculture system with aquaponics system. Overall the ammonia content in a modified conventional aquaculture system $(1.10-1.5 \mathrm{mg} / \mathrm{L})$ is higher than that of aquaponic system $(1.00-1.15$ $\mathrm{mg} / \mathrm{L}$ ). This is because in a modified conventional aquaculture system without using hydroponic circuits. Hydroponic plants utilize the nitrate content that has been converted from ammonia, by making it a nutrient for plants, which in the end, flows clean water to the fish pond.

In accordance with the study ${ }^{15}$, ammonia levels in the modified conventional aquaculture system were higher than those of the aquaponic system. This is accompanied by a higher average number of fish deaths in a modified conventional aquaculture system. Based on study ${ }^{7}$, one of the factors that influence the concentration of ammonia is the ratio of the number of fish and plants. In conventional systems, there are no hydroponic plants, so that the ammonia content is higher than the aquaponic system. Overall, ammonia values from both systems have exceeded the allowed compromise threshold, yaitu $<1 \mathrm{mg} / \mathrm{L}^{16}$, presumably, because food that is not eaten is sunk at the base of FPT, and the Nitrobacter and Nitrosomonas bacteria have not functioned optimally in converting ammonia to nitrite and nitrate.

\section{Analysis of Nitrite}

Nitrites are inorganic nitrogen compounds. In fish farming, the content of nitrite in water is dangerous for the growth of fish and plants if it exceeds the limit of $0.02 \mathrm{mg} / \mathrm{L}$. The results of the research on nitrite content in aquaponic system and modified conventional aquaculture system can be seen in Fig.-3.

In the aquaponics system (Fig.-3), the nitrite content was $0.193 \mathrm{mg} / \mathrm{L}$ on day 0 and has exceeded the concentration limit allowed for tilapia cultivation. On the $10^{\text {th }}$ day, the nitrite concentration of each tank experienced a relatively large increase. Nitrite concentration on the $20^{\text {th }}$ day also experienced a significant increase from the previous day. This increase in nitrite concentration increases with the concentration of ammonia in the water. However, on the $30^{\text {th }}$ day, the nitrite concentration decreased. This is because, on the $30^{\text {th }}$ day, it shows that the system is working optimally, which converts ammonia to nitrite.

On the $40^{\text {th }}$ day, ammonia content was compared to 30 days, nitrite concentration in FPT was $0.329 \mathrm{mg} / \mathrm{L}$, MT-1 was $0.316 \mathrm{mg} / \mathrm{L}$, BT was $0.294 \mathrm{mg} / \mathrm{L}$, MT-2 was $0.232 \mathrm{mg} / \mathrm{L}$ and HP was $0.213 \mathrm{mg} / \mathrm{L}$. Based on the final results of nitrite concentration until the $40^{\text {th }}$ day, it is known that the nitrite content is still below the threshold of the compromise of the three organisms (fish, plants, and bacteria) $<1 \mathrm{mg} / \mathrm{L}{ }^{16}$

The nitrite concentration in the modified conventional aquaculture system as a whole is higher than the aquaponics system (Fig.-3). Nitrite concentration on the $10^{\text {th }}$ day on FPT was $0.710 \mathrm{mg} / \mathrm{L}$, MT was 0.729 
RASĀYAN J. Chem.

Vol. 13 | No. 1 |1 - 10| January - March | 2020

$\mathrm{mg} / \mathrm{L}$, and BT was $0.515 \mathrm{mg} / \mathrm{L}$. On the $20^{\text {th }}$ day, the nitrite concentration increased compared to the $10^{\text {th }}$ day. But on the $30^{\text {th }}$-day nitrite concentration decreased, nitrite levels in FPT were $0.336 \mathrm{mg} / \mathrm{L}$, MT was $0.152 \mathrm{mg} / \mathrm{L}$, and BT was $0.143 \mathrm{mg} / \mathrm{L}$. Nitrite concentration decreases because nitrite has been converted to nitrate. On the $40^{\text {th }}$ day, the concentration of nitrite increased again, due to the increased ammonia content.

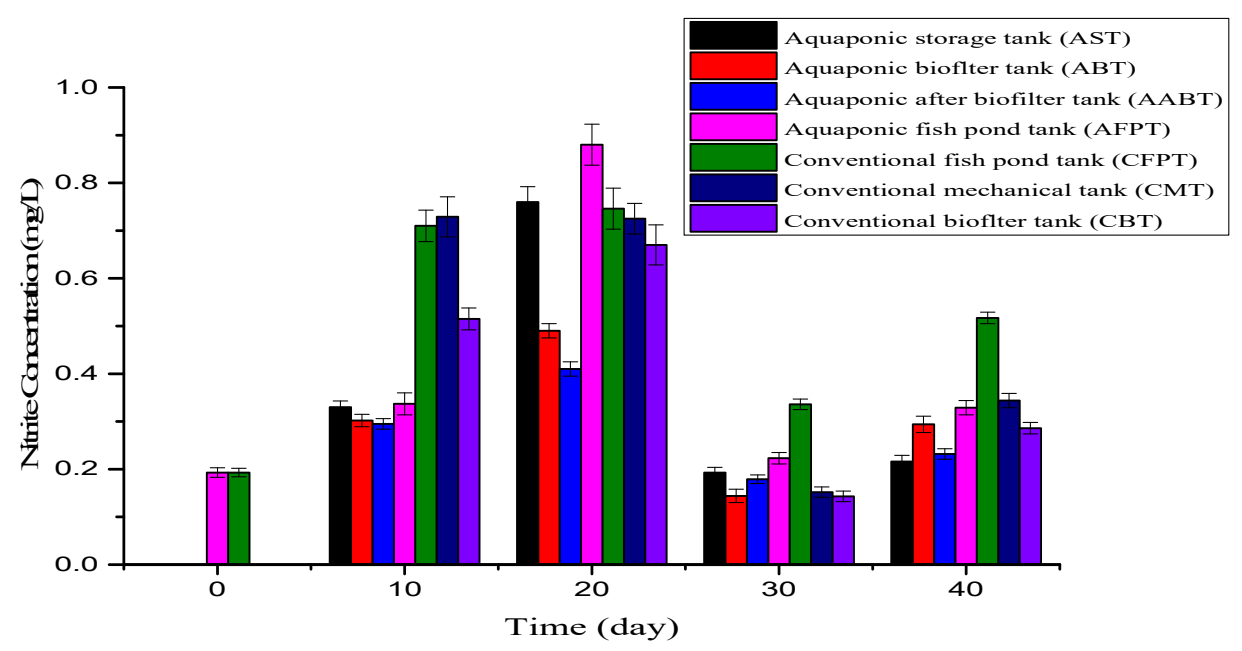

Fig.-3: Nitrite Concentration (mg/L) in Aquaponic and Modified Conventional Aquaculture

Based on Fig.-3, nitrite concentration in the modified conventional aquaculture system is higher than the aquaponics system, it is assumed that the oxygen content in the modified conventional aquaculture system is lower than the aquaponics system, so that the nitrite content in modified conventional aquaculture system accumulates more in the water than the aquaponic system.

Nitrite compounds cannot be used by plants as nutrients, so they must be broken down into nitrates with the assist of Nitrosomanas sp bacteria that need oxygen in the process. ${ }^{6}$ Excess nitrite content in water will have an effect on organisms in these waters because excessive nitrite compounds can reduce the ability of blood in organisms to bind oxygen, hemoglobin will react more strongly with nitrite compounds, which cause disruption of organism growth to cause death. ${ }^{15}$

Based on the results of studies that have been conducted, the nitrite values of the two systems are still below the allowed compromise tolerance limit, which is $<1 \mathrm{mg} / \mathrm{L}^{16}$ indicating that Nitrosococcus bacteria are able to convert nitrite to nitrate optimally.

\section{Analysis of Nitrate}

Nitrate compounds are the final products of the nitrification process which are to some extent not harmful to fish growth and can be useful for plant growth as nutrients. ${ }^{17}$ The following is an observation of the nitrate content of the FPT, MT-1, BT, MT-2, HP found in Fig.-4.

Fig.-4, in the aquaponic system, the nitrate content on day 0 was $1.031 \mathrm{mg} / \mathrm{L}$. Then there was an increase in nitrate concentration in the following days. The maximum nitrate concentration was obtained on the $30^{\text {th }}$ day, which is the nitrate content in the FPT was $5.542 \mathrm{mg} / \mathrm{L}$, MT-1 was $5.405 \mathrm{mg} / \mathrm{L}$, BT was 5.050 $\mathrm{mg} / \mathrm{L}$, MT-2 was $4.275 \mathrm{mg} / \mathrm{L}$, and HP was $4.149 \mathrm{mg} / \mathrm{L}$. The high nitrate concentration obtained is because on the $30^{\text {th }}$ day the nitrification process works optimally. This result is comparable to the small ammonia concentration on the $30^{\text {th }}$ day, indicating that ammonia has been completely converted to nitrate. On the $40^{\text {th }}$ day, there was a decrease in the level of nitrate in each tank from the previous day, it is estimated that the number of bacteria is reduced so that the bacteria cannot work optimally to meet the need for nitrates.

Fig.-4, nitrate concentrations in modified conventional aquaculture systems were overall lower than those in aquaponic systems. Nitrate concentration on the $10^{\text {th }}$ day was obtained FPT $0.248 \mathrm{mg} / \mathrm{L}$, MT was 0.433 $\mathrm{mg} / \mathrm{L}$, and BT was $0.167 \mathrm{mg} / \mathrm{L}$. On the $20^{\text {th }}$ day, there was an increase in nitrate concentration and 
RASĀYAN J. Chem.

Vol. 13 | No. 1 |1 - 10| January - March | 2020

reached maximum concentration on the $30^{\text {th }}$ day. Nitrate concentration on $30^{\text {th }}$ day FPT was $0.949 \mathrm{mg} / \mathrm{L}$, MT was $0.821 \mathrm{mg} / \mathrm{L}$, and BT was $0.716 \mathrm{mg} / \mathrm{L}$. The nitrate concentration increases to its maximum are due to the nitrification process, which is the bacteria Nitrobacter sp which converts nitrite to nitrate. On the $40^{\text {th }}$ day, there was a decrease in nitrate concentration, a concentration of FPT was $0.836 \mathrm{mg} / \mathrm{L}$, MT was $0.587 \mathrm{mg} / \mathrm{L}$, and BT was $0.256 \mathrm{mg} / \mathrm{L}$.

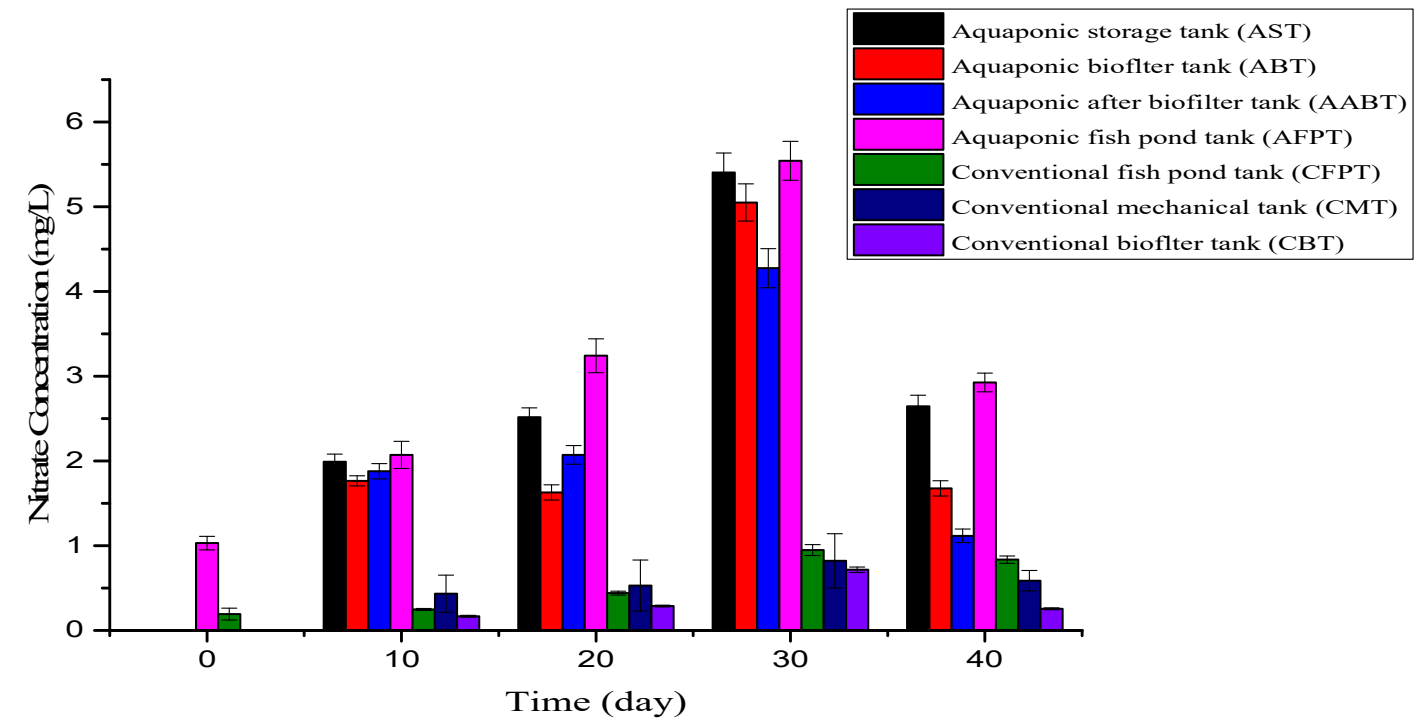

Fig.-4: Nitrate Concentration (mg/L) in Aquaponic and Modified Conventional Aquaculture

In general, the nitrate content obtained in a modified conventional aquaculture system is smaller than aquaponic system. This difference is caused by the modified conventional aquaculture system that nitrate compounds cannot be utilized maximally because there are no plants that will absorb nitrates. The low concentration of nitrate in a modified conventional aquaculture system is proportional to the low level of dissolved oxygen in the water. Decomposition of nitrite into nitrate by the bacteria Nitrobacter sp requires oxygen if the oxygen needed is not enough it will cause the nitrification process to not go well so that a small nitrate concentration is obtained.

Maximum nitrate concentration shows that the bacteria Nitrobacter sp that converts nitrite to nitrate works well so that plants can absorb nitrates well for growth. This is indicated by the maximum growth of Pakcoy plants on the $30^{\text {th }}$ day of the aquaponic system. On the $40^{\text {th }}$ day, the aquaponic system found nitrate concentrations to decrease, this was seen in the leaves of the Pakcoy plant becoming yellowish. Nitrate compounds are useful nitrogen compounds for plants, with reduced nitrate content, nutrients in plants are also reduced.

In the process of photosynthesis, plants generally need nitrogen which contains chlorophyl and sunlight which make green plants. Good nitrogen absorption by plants will increase growth because it affects the length of plant life, vegetative growth of plants can provide dyes to plants, and others. ${ }^{13}$ Based on study ${ }^{18}$, Pakcoy plants can absorb nitrate content better than spinach plants, lettuce and red spinach. The end result of the nitrification process is nitrate, which does not harm the plant if it does not exceed the limit. Based on the results of studies that have been carried out, the nitrate concentration in both systems is still below the concentration of compromise that is permitted, namely $50-150 \mathrm{mg} / \mathrm{L} .{ }^{14}$ Therefore, it is necessary to create optimal conditions for the organisms of fish, plants, and bacteria so that nitrate needs can be met.

\section{Analysis of pH}

In a recirculation system, one of the important things is $\mathrm{pH}$, because it functions as a balance between water, fish, and microbes. ${ }^{18}$ The observation of $\mathrm{pH}$ is directly measured at the sampling location, the results can be seen in Fig.-5. 
RASĀYAN J. Chem.

Vol. 13 | No. 1 |1 - 10| January - March | 2020

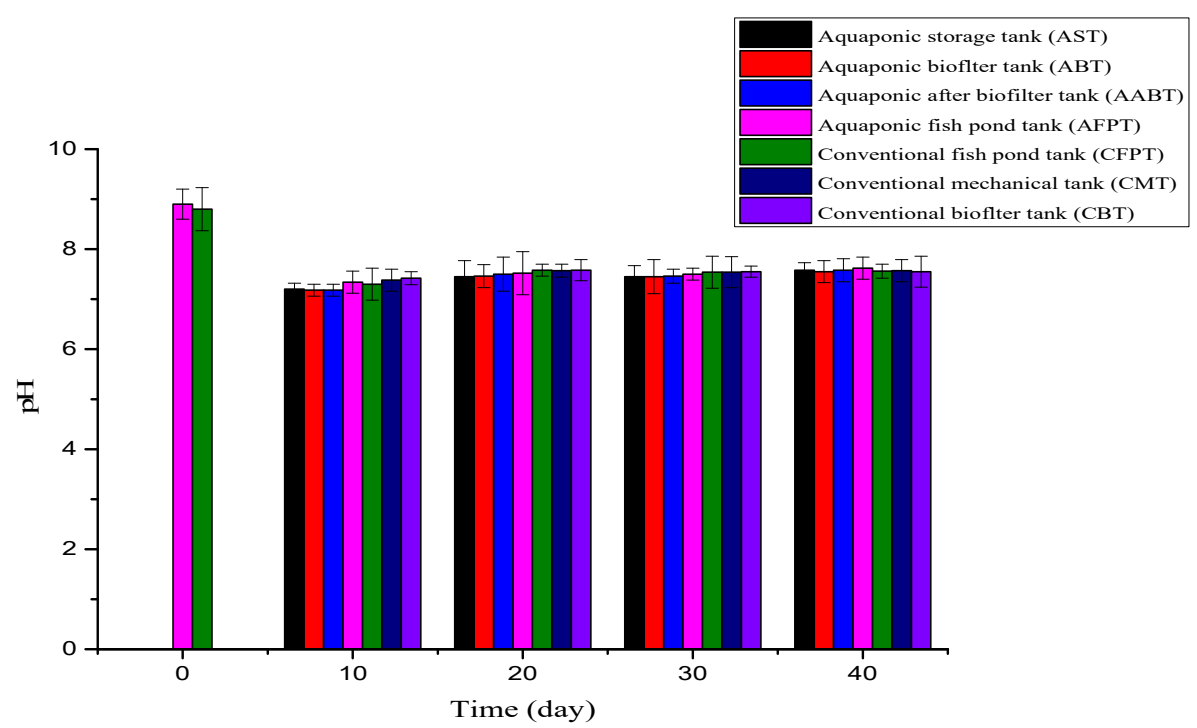

Fig.- 5: $\mathrm{pH}$ in Aquaponic and Modified Conventional Aquaculture System

Based on the observations obtained, the $\mathrm{pH}$ obtained at each sampling point in both aquaponic systems and modified conventional aquaculture systems meets dwith compromise water quality standards namely $6-7 .{ }^{11}$

On aquaponic and modified conventional aquaculture systems on the $0^{\text {th }}$ day, the $\mathrm{pH}$ values of water were 8.9 and 8.8 respectively. Then, the aquaponic system decreased on the $10^{\text {th }}$ day, in the FPT was 7.34 , MT-1 was 7.20, BT was 7.18, MT-2 was 7.18, and HP was 7.18. The pH in modified conventional aquaculture systems has decreased, namely at FPT was 7.30, MT was 7.38 and BT was 7.42. The pH value observed in the following days fluctuated and there was no significant difference with the $\mathrm{pH}$ value of the $20^{\text {th }}$ day at each sampling point. Overall, the $\mathrm{pH}$ value obtained in a modified conventional aquaculture system is higher than aquaponic system.

The difference in $\mathrm{pH}$ values in the aquaponic system and modified conventional aquaculture systems will affect the content of ammonia in water. A high $\mathrm{pH}$ value in water is an indication of pollution of ammonia $\left(\mathrm{NH}_{3}\right)$ which is more dangerous for organisms compared to ammonium $\left(\mathrm{NH}_{4}{ }^{+}\right)$from the total amount of total ammonia nitrogen in the water. If the water $\mathrm{pH}$ value exceeds 7 then ammonium $\left(\mathrm{NH}_{4}{ }^{+}\right)$will not be ionized and will react with $\mathrm{OH}^{-}$forming ammonia $\left(\mathrm{NH}_{3}\right)$ which is toxic and dangerous for fish. However, if the $\mathrm{pH}$ value of the water is less or equal to 7 then ammonium $\left(\mathrm{NH}_{4}{ }^{+}\right)$will be ionized. ${ }^{13,18}$ Therefore $\mathrm{pH}$ compromises fish, plants and bacteria tend to be slightly acidic 6-7.

$\mathrm{pH}$ values in modified conventional aquaculture systems were higher than for aquaponic systems, causes higher ammonia content in modified conventional aquaculture systems. Aquatic organisms, in general, can grow and develop at a neutral $\mathrm{pH}$ or 7 . If the $\mathrm{pH}$ of the water is too low or too high it will disrupt the condition of the growth of the organism to cause death. Tilapia is one of the freshwater fish that can grow well in the water $\mathrm{pH}$ range $6.5-9$.

\section{Influence of Temperature}

The value of water temperature obtained in the study ranged from $26.7-30.0^{\circ} \mathrm{C}$. Measurement of water temperature is carried out directly at the sampling point, the water temperature value at each point does not have a significant difference, as can be seen in Fig.-6.

Figure- 6 , on day 0 the temperature of both systems was obtained $26.3{ }^{\circ} \mathrm{C}$. Then, there was a temperature increase on the $10^{\text {th }}$ day, the water temperature on the aquaponic system in the FPT was $28.4^{\circ} \mathrm{C}$, MT- 1 was $28.4^{\circ} \mathrm{C}$, BT was $28.4^{\circ} \mathrm{C}$, MT-2 was $28.3^{\circ} \mathrm{C}$, and HP was $28.2^{\circ} \mathrm{C}$. Likewise on the $10^{\text {th }}$ day in the modified conventional aquaculture system in the FPT was $28.5^{\circ} \mathrm{C}$, MT was $29.4^{\circ} \mathrm{C}$ and BT was $29.3^{\circ} \mathrm{C}$. On the $30^{\text {th }}$ and $40^{\text {th }}$ day the water temperature values experienced small fluctuations at each sampling point. 
RASĀYAN J. Chem.

Vol. 13 | No. 1 |1 - 10| January - March | 2020

The influence of weather conditions affects the temperature that causes the difference at each point. The increase in temperature on the $20^{\text {th }}$ day is proportional to the decrease in oxygen levels in the water because if the water temperature increases it will increase the consumption of oxygen in the water for each organism. ${ }^{18}$ Reduced oxygen levels in the water will affect the activity of bacteria that require oxygen in the nitrification process, causing an increase in the content of ammonia in water. The activity and behavior of fish are influenced by the temperature if the temperature is too low or too high will cause competition between fish to obtain oxygen. Based on the results of the study ${ }^{19}$, the water temperature will affect the specific level of fish growth and the conversion ratio of eating fish.

The results obtained the water temperature in the aquaponic system and the modified conventional aquaculture system meets with the compromised water quality allowed $18-30^{\circ} \mathrm{C}^{11}$, and feasible for the development of both systems.

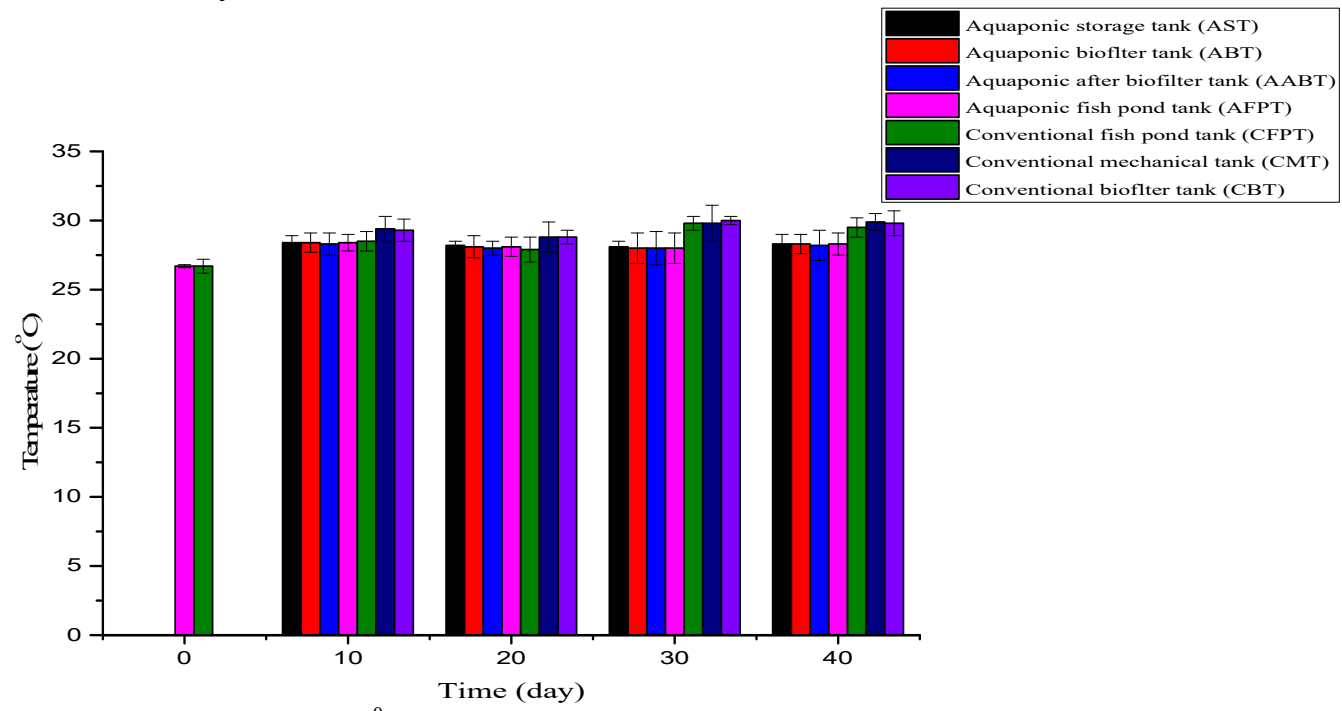

Fig.-6: Temperature $\left({ }^{0} \mathrm{C}\right)$ in Aquaponic and Modified Conventional Aquaculture System

\section{CONCLUSION}

It can be concluded that aquaponic system and modified conventional aquaculture system showed a significant difference where the aquaponic system was better than the modified conventional aquaculture system because the aquaponic system was supported by the presence of MT-1, BT, MT-2, HP, and FPT, while the modified conventional aquaculture systems were only supported by MT, BT, and FPT.

\section{ACKNOWLEDGMENT}

The authors would like to thank Andalas University, which has funded research on the acceleration of professors on May 14, 2019, Contract Number: 43/UN.16.17/PP.PGB/LPPM/2019.

\section{REFERENCES}

1. R. Sharad, O.P. Surnar, V.P. Sharma, V.P. Saini. Int. J. Fisheries and Aquatic Studies, 2, 261(2015).

2. S. Diver. Aquaponic-integration hydroponic with aquaculture. National centre of appropriate technology. Department of Agriculture's Rural Bussiness Cooperative Service, (2006).

3. D.C. Love, J.P. Fry, X. Li, E.S. Hill, L. Genello, K. Semmens, R.E. Aquaculture, 435, 67(2015), DOI:10.1016/j.aquaculture.2014.09.023

4. L. A. Helfrich, G. Libey. Fish farming in recirculating aquaculture system (RAS). Department of Fisheries and Wildlife Sciences. Virginia Tech. (2000).

5. B. Delaide, G. Delhaye, M. Dermience, J. Gott, H. Soyeurt, M. Haissam, Aquacultural Eng.(2017), DOI: $10.1016 /$ j.ejrad.2017.05.043 \

6. E. Okemwa. Int. J. Sci. R. Innovative Technol., 2, 12(2015). 
RASĀYAN J. Chem.

Vol. 13 | No. 1 |1 - 10| January - March | 2020

7. Deswati, N. Febriani, H. Pardi, Y. Yusuf, H. Suyani. Oriental J. Chem., 34, 2447(2018), DOI: 10.13005/ojc/340529

8. Deswati, A. K. Muchtar, E.F. Abe, H. Pardi, Y. Yusuf, H. Suyani. Rasayan J. Chem., 12, 40(2019), DOI:10.31788/RJC.2019.1215062

9. L. Sarido, Junia. Agrifor. J., 16, 65(2017).

10. T. Popma, M. Masser. Int. Biodeterioration \& Biodegradation, 125, 24( 2017).

11. Anonymous, Small Scale Aquaponis, Training Manual, Addis Ababa, Ethiopia, 2014

12. M.P. Masser, J. Rakocy, T.M. Losordo, Recirculating Aquaculture Tank Production Systems: Management of Recirculating Systems, Southern Regional Aquaculture Center Publ. No. 452, (1999).

13. R.A. Nugroho, L.T. Pambudi, D. Chilmawati, A.H.C. Haditomo. Sci. J. Fisheries, 8, 46(2012).

14. G. Suantika, M.I. Pratiwi, M.L. Situmorang, Y.A. Djohan, H. Muhammad, D.I. Astuti. Pout, Fish\& Widl. Sci, 4, 1(2016).

15. S. Samsundari, G. A. Wirawan, Analysis of the Application of Biofilter in the Recirculation System to the Quality of Water Quality in Cultivating Eel (Anguilla bicolor), Faculty of Agriculture and Animal Husbandry, Muhammadiyah University of Malang, (2013).

16. FAO Fisheries And Aquaculture Technical Paper 589, Small Scale Aquaponic Food Production Integrated Fish and Plant Farming, 2014.

17. Nurhidayat, K. Nirmala, D. Djokosetiyanto. J. Ris. Aquaculture., 7, 2(2012).

18. Y. Zou, Z. Hu, J. Zhang, C. Guimbaud, Q. Wang, Y. Fang. J. Ecological Eng., 94, 30(2016), DOI: 10.1016/j.ecoleng.2016.05.063

19. J. E. Rakocy, R. L. Nelson, G. Wilson. Aquaponic J., 4, 8(2005), DOI: 10.17660/ActaHortic.2007.742.28

[RJC-5427/2019] 